\title{
THE COST OF KARST SUBSIDENCE AND SINKHOLE COLLAPSE IN THE UNITED STATES COMPARED WITH OTHER NATURAL HAZARDS
}

\author{
David J. Weary \\ U.S. Geological Survey, 12201 Sunrise Valley Drive, MS926A, Reston,VA, 20192, USA,dweary@usgs.gov
}

\begin{abstract}
Rocks with potential for karst formation are found in all 50 states. Damage due to karst subsidence and sinkhole collapse is a natural hazard of national scope. Repair of damage to buildings, highways, and other infrastructure represents a significant national cost. Sparse and incomplete data show that the average cost of karst-related damages in the United States over the last 15 years is estimated to be at least $\$ 300,000,000$ per year and the actual total is probably much higher. This estimate is lower than the estimated annual costs for other natural hazards; flooding, hurricanes and cyclonic storms, tornadoes, landslides, earthquakes, or wildfires all of which average over \$1 billion per year. Very few state organizations track karst subsidence and sinkhole damage mitigation costs; none occurs at the federal level. Many states discuss the karst hazard in their state hazard mitigation plans, but seldom include detailed reports of subsidence incidents or their mitigation costs. Most state highway departments do not differentiate karst subsidence or sinkhole collapse from other road repair costs. Amassing of these data would raise the estimated annual cost considerably. Information from insurance organizations about sinkhole damage claims and payouts is also not readily available. Currently there is no agency with a mandate for developing such data. If a more realistic estimate could be made, it would illuminate the national scope of this hazard and make comparison with costs of other natural hazards more realistic.
\end{abstract}

\section{Introduction}

Karst subsidence in the United States, particularly catastrophic sinkhole collapse, is a significant natural hazard with national scope. Although the potential for subsidence or sinkhole occurrence is aerially variable, areas underlain by relatively soluble carbonate and evaporite rocks exist in all 50 states (Figure 1).

Sinkhole collapse tends to occur more often in the eastern part of the country, where there is generally higher rainfall and where local geologic settings are conducive to formation of cover-collapse sinkholes, such as soluble rocks overlain by variable thicknesses of sediment or soil. The New England states are less prone to sinkholes because many sinkholes which may have formed in the bedrock surface have been removed by glacial scouring.
While fatalities, or even injuries, are rare, karst subsidence and sinkhole collapses damage man-made structures and cost the nation many millions of dollars each year. In addition, land values in sinkhole-prone areas can become depressed, impacting not just land owners, but also counties and municipalities that are dependent on real estate and property tax revenue.

Unlike other natural hazards, sinkhole collapse is generally not dependent on extreme weather events and can occur, sporadically, across the country every year. Man-made infrastructure and buildings and transportation arteries have expanded onto karst terrain that was formerly rural and sparsely developed. Features such as water supply pipes, storm drains, and sewers, already built over karst, are failing at higher rates as they age, particularly if they have not been maintained.

\section{The Problem}

Karst subsidence and sinkhole collapse is a significant natural hazard. The problem is determining just how much it costs the United States annually and where it ranks compared with other hazards such as hurricanes, floods, earthquakes, landslides, volcanoes, and tsunami. There is no comprehensive national database documenting the occurrence of karst subsidence or sinkhole collapse, or their cost. There is also little cost information available from most States. Most researchers, when asked about the level of economic impact of karst hazard, familiar with the subject will reply "great question, we wish we knew!" Publically available scientific and trade literature, and news media reports, generally contain vague accounts of sinkholes, and sinkhole damage. They rarely include accurate damage cost estimates. It is also difficult to determine whether a reported "sinkhole" is actually a natural collapse into a karst void or manmade void or whether it was man-initiated. For example, did the leaking water pipe cause the subsurface void and sinkhole collapse, or did collapse of a natural sinkhole cause the overlying water pipe to break? The hazard is very real, as evidenced by the amount of money involved in sinkhole insurance premiums and payouts. State and local governments may be reluctant to track and report sinkhole damages, because such information may lead to reduced property values and a reduction in the property tax base. 


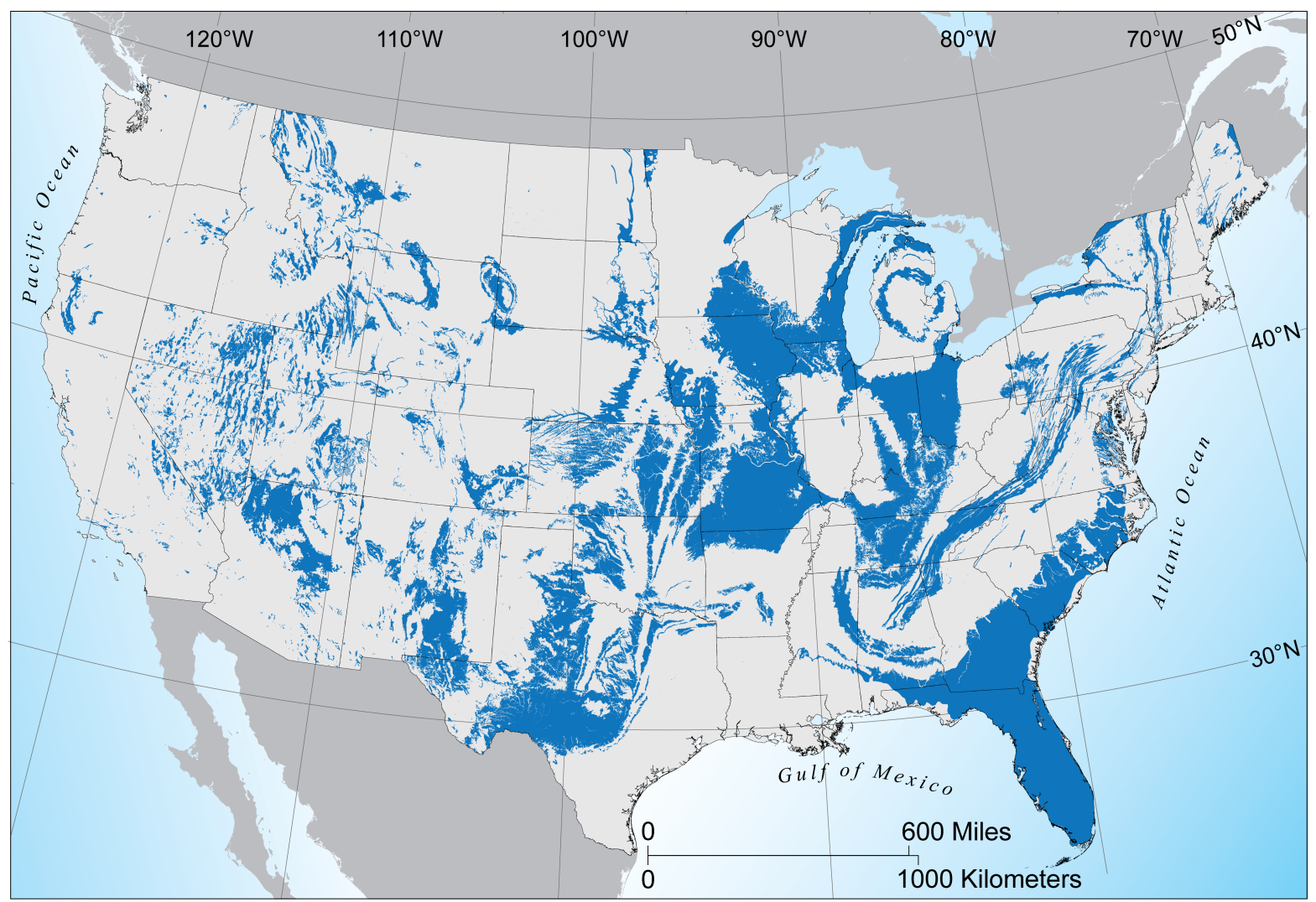

Figure 1. Map of the contiguous United States showing areas, in blue, underlain by relatively soluble rocks with variable potential for karst development. These include carbonate and evaporite rocks at or near the ground surface. Alaska and Hawaii (not shown) also have areas underlain by soluble rocks. Figure modified from Weary and Doctor (2014).

There is a growing awareness among national natural hazard management agencies, insurance organizations, highway departments, and karst scientists that the costs of the karst hazard, in terms of property damage, is significant. There has been, however, little political or institutional support for data collection, scientific studies, or mitigation programs partly because there is very little data documenting the totality of karst subsidence and sinkhole costs at national, state, or even municipal levels. Also, the karst hazard tends to be manifested by scattered and sporadic individual events that are local in scope. Although karst collapse is sometimes very costly locally, they often fail to reach thresholds where they become worrisome to the general public and their civic leaders. Although there have been some spectacular, but limited, collapse incidents, there has never been a presidentially declared sinkhole disaster. In aggregate, however, the costs induced by sinkhole collapses across the United States are significant and may be large enough to compare with other natural hazards. States that are aware of their sinkhole hazard tend to keep incomplete records of karst incidents.
The purpose of this paper is to attempt to outline an estimate of the cost of karst subsidence and sinkhole hazard in the United States and to emphasize the lack of hard data available at almost all scales. The intent of this paper was to try and describe the problem and elucidate the need for data, and not to create an exhaustive national database.

\section{Definitions}

Impediments to public and official acknowledgement of the true magnitude of karst hazards include a lack of understanding of the processes involved, as well as nonstandard definitions of collapse features. It is common for the news media to report any type of collapse, regardless of cause, as a sinkhole. More often than not these turn out to be collapses in man-made fill and are caused by leaking pipes or drains rather than related to karst processes. Some reports even describe highway potholes, caused by separation of paving materials by freeze-thaw and other processes, as sinkholes. In the context of this study, the term sinkhole refers only to those depressions that result from natural karstic processes. 


\section{Karst}

The term karst has traditionally been used to refer to regions of exposed or only shallowly buried soluble bedrock with an abundance of surface landforms, such as sinkholes, sinking streams, springs that reflect the presence of subsurface voids (caves) (Ford and Williams, 2007). All 50 of the United States as well as most of the territories and islands contain areas of karst (Figure 1). About $18 \%$ of the ground surface of the United States is underlain by soluble rocks and sediments with potential for sinkhole development (Weary and Doctor, 2014).

\section{Subsidence}

Subsidence is the lowering of the ground surface, either as a gradual and slow process or as a sudden and rapid collapse. Karst subsidence of broad areas is caused by karstic processes of dissolution at the surface or in the subsurface and is so slow that it generally does not constitute a threat to the health and wellbeing of people and animals. This subsidence is often so slow that it does not affect structures, although in some cases it can cause foundation cracking and tilting. There are other kinds of subsidence associated with groundwater withdrawal, mining, and other activities, but they are not addressed in this report.

\section{Sinkholes}

Sinkholes are closed topographic depressions caused by a lowering of the earth surface by dissolution of the bedrock or by collapse of the surface into a void produced by solution or removal of subterranean materials. A karst sinkhole is produced by natural processes of solution of the bedrock, sometimes followed by collapse of overlying sediments or soil. For the remainder of this paper, the term 'sinkhole' will refer only to karst sinkholes.

Sinkholes may be divided into several types based on their morphology and the processes involved in their formation. These sinkhole types are: (1) dissolution, (2) cover-subsidence, (3) cover-collapse, and (4) bedrock collapse. See Galloway et al. (1999) for simple descriptions of the first three types. The fourth type, bedrock collapse, is rare and not discussed in that publication or in this report. Most injury and damage resulting from karst subsidence in the U.S. is caused by the cover-collapse type of sinkholes. This is because these sinkholes are relatively common, they often occur without warning as sudden ground failures, and since they occur where there is a soil or sediment mantle over the bedrock their precise locations are difficult to anticipate.

Sinkholes can form over various periods of time. Many were formed many years before the present and, although they indicate solution of the bedrock, they may not pose a threat of future collapse. These depressions might be termed 'topographic sinkholes' or possibly 'inactive sinkholes'. Sinkholes that have formed in very recent time, particularly as sudden collapses may be termed 'active sinkholes' and can indicate instability in the soil or sediment cover of the areas in which they are found. Most sinkholes in state sinkhole databases tend to be based on topographic maps and are of the 'inactive' or 'topographic type'.

\section{Karst hazard}

In the context of this report, karst hazard refers to both subsidence and collapse caused by natural karst processes or by other processes working on natural karst features.

\section{Annual cost of karst subsidence in the United States}

FEMA (1997) conservatively estimated losses to all types of ground subsidence, including karst, to be at least \$125 million per year in the U.S., a very low figure indeed.

Florida is generally accepted as the state most adversely affected by karst collapse. Other sinkhole-prone states include: Texas, Alabama, Missouri, Kentucky, Tennessee, and Pennsylvania. This list is attributed to the U.S. Geological Survey (USGS) where it appears on a few informational webpages (for example see the USGS Water Sciences School webpage at: http://water.usgs.gov/edu/ sinkholes.html). This list appears to be ad hoc, anecdotally-based, and there is no substantive reference for it. There is inadequate sinkhole data available to authoritatively evaluate the relative ranking of these states, or even whether they actually rank within the top seven of all states for occurrence of damaging sinkholes. Many states other than those on the list are also adversely affected by karst hazards to various degrees.

The U.S. Disaster Mitigation Act of 2000 mandates that states must have in place a FEMA-approved standard State Hazard Mitigation Plan to remain eligible for preand post-disaster federal hazard mitigation funding. The plan lists significant potential natural hazards that may be expected to impact that state. A review of each state's multi-hazard mitigation plan, most of them 2013 documents, reveals that 29 of the 50 states discuss karst subsidence as a potential hazard and the remainder apparently do not consider karst hazard as significant enough to discuss in their plan (Figure 2). Interestingly, several states known to have abundant karst features, such as Indiana, Illinois, and Arkansas, do not discuss the karst hazard in their hazard mitigation plans. 


\section{Methodology}

Because of the lack of comprehensive statistics on karst subsidence/sinkhole collapse damage costs, it is impossible to generate a reasonably accurate estimate of the annual cost due to this nationwide. An examination of readily available cost data from the most sinkhole affected states can provide a lower boundary. The actual costs are very probably much higher than the sum of those reported. Any of the cost estimates contained in this report should be considered uncertain as the data are incomplete and many of the data sources used were secondary in nature.

If there was an authoritative estimate of sinkhole damage cost within a state, that figure was used with citation. This was true only for Florida, Kentucky, and Virginia. For each State where estimates of sinkhole damage costs were not available such costs were generated from an analysis of publicly available data. Such sources include: (1) Sinkhole incident and cost information described

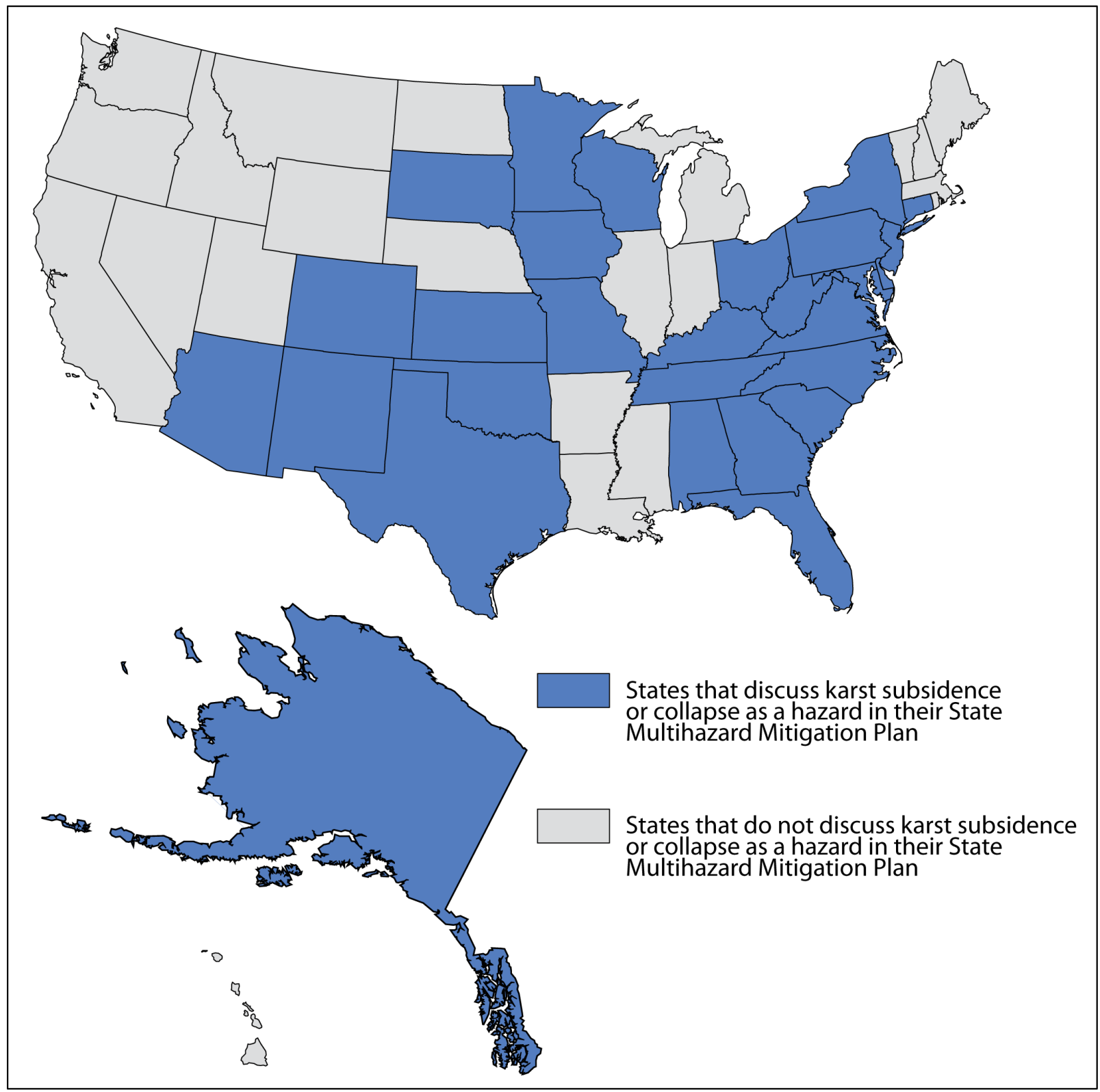

Figure 2. Map showing states that discuss karst as a hazard in their State hazard mitigation plan. This figure is based chiefly on 2013 updates to most plans. These plans can usually be found at each state's emergency management agency website. 
in each States' hazard mitigation plan; (2) An internet search for reports of sinkhole damage incidents and costs by city or county; (3) An internet search for sinkhole repair reports from each State department of transportation; and, (4) An internet search for sinkhole incident reports and costs statewide for each year for the period 2000-2014. Cities and counties listed as impacted by sinkhole hazard in the state hazard mitigation plans were used as keywords for specific searches. These internet searches were cursory, employing a popular search engine and the keywords: [city or county name], sinkhole, cost, damage, and state. I generally examined only the first several pages of search returns. Extended links from these search results were often followed in an attempt to find additional information on incidents reported or alluded to. I examined each incident report and used my judgment, based on the geologic setting and the source's description of the 'sinkhole', to decide whether to include it in the state sinkhole cost estimate. Many incidents were obviously not karst sinkholes and were not included. Individual incidents identified in the searches are listed by state in Table 1 .

No attempt was made to adjust reported cost amount for inflation, the raw numbers were used. All costs identified for the years 2000-2014 were summed and the average cost per state per year calculated. These averages were then summed to produce a rough minimal estimate of cost to the United States per year.

Other karst-related damage or remediation costs, like ongoing rehabilitation of leaking dams built over karst such as the Wolf Creek Dam, Kentucky, estimated at $\$ 300$ million (Carey and others, 2008), the Rough Creek Dam, Kentucky at $\$ 149,800,000$. (U.S. Army Corps of Engineers, 2014), the Center Hill Dam, Tennessee, at \$364 million (U.S. Army Corps of Engineers, 2015), and Clearwater Lake, Missouri, for $\$ 240,663,000$ (U.S. Army corps of Engineers, 2012) were not included in the calculation. The estimate is principally limited to

\begin{tabular}{|c|c|c|c|c|}
\hline STATE & YEAR & COST & DESCRIPTION & REFERENCE \\
\hline Alabama & 2007 & $\$ 1,100,000$ & $\begin{array}{l}\text { Hanson and Oldcastle (Quarry } \\
\text { owners) settle lawsuit with City } \\
\text { of Opelika }\end{array}$ & $\begin{array}{l}\text { http://www.aggregateresearch.com/ } \\
\text { articles/13175/Hanson-and-Oldcastle- } \\
\text { settle-11-million-lawsuit-with-City-of- } \\
\text { Opelika.aspx. }\end{array}$ \\
\hline Alabama & 2007 & $\$ 100,000$ & $\begin{array}{l}\text { City of Madison House over } \\
\text { sinkhole. Cost of geotechnical } \\
\text { evaluation only }\end{array}$ & $\begin{array}{l}\text { http://blog.al.com/huntsville/2010/07/ } \\
\text { the_comeback_of_the_former_sin.html }\end{array}$ \\
\hline Alabama & 2008 & $\$ 350,000$ & City of Tarrant sinkhole repairs & $\begin{array}{l}\text { http://www.al.com/birminghamnews/ } \\
\text { stories/index.ssf?/base/commun- } \\
\text { ty/1224663393133860.xml\&coll=2 }\end{array}$ \\
\hline Alabama & 2009 & $\$ 68,000$ & $\begin{array}{l}\text { City of Birmingham buys our } \\
\text { sinkhole house }\end{array}$ & $\begin{array}{l}\text { http://www.al.com/news/index. } \\
\text { ssf/2009/03/31/ }\end{array}$ \\
\hline Alabama & 2010 & $\$ 3,000,000$ & $\begin{array}{l}\text { Morgan County, I-65 sinkhole } \\
\text { repair }\end{array}$ & $\begin{array}{l}\text { http://www.fhwa.dot.gov/pressroom/ } \\
\text { fhwa1221.cfm }\end{array}$ \\
\hline Alabama & 2010 & $\$ 48,250$ & $\begin{array}{l}\text { City of Madison, grouting of } \\
\text { sinkhole }\end{array}$ & $\begin{array}{l}\text { http://www.madisonal.gov/Document- } \\
\text { Center/Home/View/1932 }\end{array}$ \\
\hline Alabama & 2012 & $\$ 300,000$ & $\begin{array}{l}\text { Calhoun County, I-20 sinkhole } \\
\text { repair }\end{array}$ & $\begin{array}{l}\text { http://www.dot.gov/briefing-room/us- } \\
\text { transportation-secretary-anthony-foxx- } \\
\text { announces-3339-million-emergency- } \\
\text { relief-road }\end{array}$ \\
\hline Alabama & 2013 & $\$ 200,000$ & $\begin{array}{l}\text { City of Birmingham, baseball } \\
\text { stadium sinkhole repair }\end{array}$ & $\begin{array}{l}\text { http://blog.al.com/spotnews/2013/01/ } \\
\text { massive_sinkhole_at_birmingham.html }\end{array}$ \\
\hline Alabama & 2013 & $\$ 1,000,000$ & City of Oxford, sinkhole repair & $\begin{array}{l}\text { http://www.montgomeryadvertiser.com/ } \\
\text { article/20130816/NEWS02/308160014/ } \\
\text { Oxford-sinkhole-common-northern-Ala- } \\
\text { bama }\end{array}$ \\
\hline
\end{tabular}

Table 1. Sinkhole incidents and associated costs from the years 2000-2014. Websites referenced were accessed 6/03/2015. 


\begin{tabular}{|c|c|c|c|c|}
\hline STATE & YEAR & COST & DESCRIPTION & REFERENCE \\
\hline Alabama & 2015 & $\$ 9,400,000$ & $\begin{array}{l}\text { Repair of sinkholes in Ala- } \\
\text { bama Route } 21\end{array}$ & $\begin{array}{l}\text { http://www.annistonstar.com/the_daily } \\
\text { home/dh_news/article_fba2867e-b195- } \\
\text { 5726-b2bc-b0c68546542e.html }\end{array}$ \\
\hline Indiana & 2014 & $\$ 11,000,000$ & $\begin{array}{l}\text { Repair of sinkholes under } \\
\text { Monroe County Airport }\end{array}$ & $\begin{array}{l}\text { http://www.airportimprovement.com/ } \\
\text { article/monroe-county-airport-repairs- } \\
\text { airfield-sinkholes }\end{array}$ \\
\hline Maryland & 2003 & $\$ 2,000,000$ & $\begin{array}{l}\text { Frederick County, new Design } \\
\text { Road sinkhole repair }\end{array}$ & $\begin{array}{l}\text { http://www.brunswickmd.gov/wp-con- } \\
\text { tent/uploads/2012/01/Frederick-County- } \\
\text { Hazard-Mitigation-Plan-Final1.pdf }\end{array}$ \\
\hline Maryland & 2007 & $\$ 217,141$ & $\begin{array}{l}\text { Washington County, Maugans } \\
\text { Avenue sinkhole repair }\end{array}$ & $\begin{array}{l}\text { http://www.washco-md.net/washco_2/ } \\
\text { pdf_files/packets/2007/070717/ARF } \\
\text { Maugans\%20Sinkhole\%20Grouting.pdf }\end{array}$ \\
\hline Missouri & 2004 & $\$ 650,000$ & $\begin{array}{l}\text { Lake Chesterfield drained, } \\
\text { sinkhole repaired }\end{array}$ & $\begin{array}{l}\text { http://www.semissourian.com/sto- } \\
\text { ry/2022983.html }\end{array}$ \\
\hline Missouri & 2006 & $\$ 50,000$ & $\begin{array}{l}\text { City of Nixa, Scrivener sink- } \\
\text { hole. Cost for city to close } \\
\text { hole; not including house and } \\
\text { car losses }\end{array}$ & $\begin{array}{l}\text { http://articles.kspr.com/2013-07-18/sink- } \\
\text { hole_40662901 }\end{array}$ \\
\hline Missouri & 2010 & $\$ 30,000$ & $\begin{array}{l}\text { City of Nixa, new sinkhole } \\
\text { repair, developer's estimate to } \\
\text { fill }\end{array}$ & $\begin{array}{l}\text { http://articles.ky3.com/2010-12-02/sink- } \\
\text { hole_25004905 }\end{array}$ \\
\hline Missouri & 2014 & $\$ 1,200,000$ & $\begin{array}{l}\text { City of Cape Girardeau, sink- } \\
\text { hole road repairs }\end{array}$ & $\begin{array}{l}\text { http://www.semissourian.com/sto- } \\
\text { ry/2140640.html }\end{array}$ \\
\hline Pennsylvania & 2001 & $\$ 17,000,000$ & $\begin{array}{l}\text { Pennsylvania Department of } \\
\text { Transportation, US 202, US } \\
\text { 422-I, } 76 \text { highway interchange } \\
\text { project sinkhole remediation }\end{array}$ & $\begin{array}{l}\text { http://www.pahighways.com/us/US202. } \\
\text { html }\end{array}$ \\
\hline Pennsylvania & 2004 & $\$ 6,000,000$ & $\begin{array}{l}\text { Stockertown, rebuilding of } \\
\text { Route } 33 \text { bridges over Bush- } \\
\text { kill Creek }\end{array}$ & $\begin{array}{l}\text { http://www.lvpc.org/pdf/hazardMitiga- } \\
\text { tion/hazardMitigation.pdf }\end{array}$ \\
\hline Pennsylvania & 2004 & $\$ 300,000$ & $\begin{array}{l}\text { City of Easton, St. John Street, } \\
\text { street repairs. Several dam- } \\
\text { aged buildings not included }\end{array}$ & $\begin{array}{l}\text { http://www.lvpc.org/pdf/hazardMitiga- } \\
\text { tion/hazardMitigation.pdf }\end{array}$ \\
\hline Pennsylvania & 2011 & $\$ 50,000$ & $\begin{array}{l}\text { Nazareth Township, Middle } \\
\text { School track sinkhole repair }\end{array}$ & $\begin{array}{l}\text { http://www.lehighvalleylive.com/naza- } \\
\text { reth/index.ssf/2011/08/nazareth_school_ } \\
\text { board_to_spend.html }\end{array}$ \\
\hline Pennsylvania & 2011 & $\$ 210,000$ & $\begin{array}{l}\text { Whitehall Township, private } \\
\text { home sinkhole repair }\end{array}$ & $\begin{array}{l}\text { http://articles.mcall.com/2011-12-03/ } \\
\text { news/mc-watchdog-whitehall-sink- } \\
\text { hole-20111203_1_sinkholes-disaster- } \\
\text { relief-disaster-area }\end{array}$ \\
\hline Pennsylvania & 2014 & $\$ 4,000,000$ & $\begin{array}{l}\text { City of Harrisburg, 14th Street } \\
\text { sinkholes, repair estimate }\end{array}$ & $\begin{array}{l}\text { http://www.pennlive.com/mid- } \\
\text { state/index.ssf/2014/11/harrisburg } \\
\text { sinkholes_14th_stre.html }\end{array}$ \\
\hline
\end{tabular}

Table 1 Continued. Sinkhole incidents and associated costs from the years 2000-2014. Websites referenced were accessed 6/03/2015. 


\begin{tabular}{|c|c|c|l|l|}
\hline STATE & YEAR & COST & DESCRIPTION & REFERENCE \\
\hline Pennsylvania & 2014 & $\$ 844,422$ & $\begin{array}{l}\text { Pennsylvania Department of } \\
\text { Transportation project to make } \\
\text { sinkhole repairs on U.S. Route } \\
\text { 422 near Palmyra }\end{array}$ & $\begin{array}{l}\text { http://www.dot.state.pa.us/Penndot/ } \\
\text { Districts/D8news.nsf/a2a8ee9f2c47a- } \\
\text { 24b8525783a004f753a/b7eef5ea2f6e8 } \\
\text { 44f85257d240052d2f8?OpenDocume } \\
\text { nt }\end{array}$ \\
\hline $\begin{array}{c}\text { South } \\
\text { Carolina }\end{array}$ & 2014 & $\$ 4,167,280$ & $\begin{array}{l}\text { City of Georgetown, repairs to } \\
\text { municipal buildings damaged by } \\
\text { sinkholes }\end{array}$ & $\begin{array}{l}\text { http://gtweb.epp.dc.publicus.com/arti- } \\
\text { cle/20141231/GTT06/141239982/1129 }\end{array}$ \\
\hline Tennessee & 2010 & $\$ 267,000$ & $\begin{array}{l}\text { Tennessee Department of Trans- } \\
\text { portation, I-24 Grundy County } \\
\text { sinkhole repair }\end{array}$ & $\begin{array}{l}\text { h t t p ://w w w . w r c b t v . c o m / } \\
\text { story/12508049/i-24-east-in-grundy- } \\
\text { county-opens-after-sinkhole-repaired? } \\
\text { clienttype=printable }\end{array}$ \\
\hline Tennessee & 2012 & $\$ 39,450$ & $\begin{array}{l}\text { Unicoi County, Love Chapel } \\
\text { Elementary School sinkhole, } \\
\text { temporary stabilization and re- } \\
\text { locations costs only. School was } \\
\text { eventually abandoned. }\end{array}$ & $\begin{array}{l}\text { http://www.johnsoncitypress.com/ar- } \\
\text { ticle/102376 }\end{array}$ \\
\hline Tennessee & 2013 & $\$ 100,000$ & $\begin{array}{l}\text { City of Knoxville, private home } \\
\text { sinkhole damages }\end{array}$ & $\begin{array}{l}\text { http://www.wbir.com/news/arti- } \\
\text { cle/264022/2/Sinkhole-nearly-bank- } \\
\text { rupts-West-Knoxville-homeowner }\end{array}$ \\
\hline Tennessee & 2013 & $\$ 40,000$ & $\begin{array}{l}\text { City of Oak Ridge, soccer field } \\
\text { sinkhole repairs }\end{array}$ & $\begin{array}{l}\text { http://www.knoxnews.com/news/local- } \\
\text { news/soccer-sinkhole-moves-games- } \\
\text { costs-school-system }\end{array}$ \\
\hline Tennessee & 2014 & $\$ 250,000$ & $\begin{array}{l}\text { City of Knoxville, Kindle Road } \\
\text { sinkhole repairs }\end{array}$ & $\begin{array}{l}\text { http://www.wbir.com/story/news/local/ } \\
\text { west-knoxville-farragut/2014/01/15/ } \\
\text { repairs-planned-for-kendall-road-sink- } \\
\text { hole/4502693/ }\end{array}$ \\
\hline
\end{tabular}

Table 1 Continued. Sinkhole incidents and associated costs from the years 2000-2014. Websites referenced were accessed 6/03/2015.

structural damages and remediation and not to personal property loss, such as cars and other valuable items.

Because of the limited scope of this investigation, only states with large areas of karst and located in the eastern part of the U.S. were examined for damage cost reports. Karst subsidence and sinkhole collapses in the western part of the country certainly occur, but are less common. Some of the western states are increasingly encountering karst, such as Colorado, because of human development expansion into areas underlain by evaporite rocks. Some western regions are also affected by gradual subsidence as a result of natural dissolution of deeply-buried salt deposits.

\section{Alabama}

Large areas of Alabama are underlain by carbonate rocks and are susceptible to sinkhole collapse. One of the largest recent sinkhole collapses in the United States occurred in Shelby County in 1972 with the sudden for- mation of a 325 feet long by 300 feet wide and 120 feet deep "Golly Hole". Fortunately this collapse occurred in a rural area and no injuries or significant property damage occurred. The Alabama Emergency Management Agency (2013) reported recent sinkhole collapse of buildings and infrastructure in, and near, the cities of: Sylacauga, Opelika, Valley Head, Huntsville, Auburn, Phenix City, Montevallo, Alabaster, Gadsden, Birmingham, Tuskegee, and Trussville.

For the years 2000-2014 there are reports of at least $\$ 15,566,250$ in sinkhole damage repairs, a 15 year average of $\$ 1,037,750$, per year (Table 1).

\section{Arkansas}

While sinkholes certainly occur, particularly in the Ozark Plateaus region in the north part of the state, no records were found documenting sinkhole collapse damage costs in Arkansas. 


\section{Florida}

Insurance sources in Florida reported over $\$ 84$ million in sinkhole losses plus adjustment expenses in 2009, The Florida Office of Insurance Regulation (2010) reported that insurers had received 24,671 claims for sinkhole damage in Florida between 2006 and 2010 totaling \$1.4 billion, an average of $\$ 280$ million per year for those five years. These figures do not include annual costs incurred by the Florida Department of Transportation in highway repairs due to karst subsidence. In Florida the loss partly comes from gradual subsidence damage to homes and other structures, as well as incidents involving outright collapses. Some portion of the insured damages, such as foundation cracking, are probably caused by non-karst processes such as differential settling, expansive soils, or poor building practices.

\section{Georgia}

There were several news media reports mentioning sinkholes, but all were related to failed storm water drainage structures. The Georgia Emergency Management
Agency (2014) discussed the geology and geography of potential sinkhole areas in the state, but has no data on specific incidents or costs.

\section{Indiana}

Indiana is underlain by large areas of karst and has many known sinkholes. Sinkhole damage and threat of further collapse to the Monroe county airport, first noticed in the 1990's was repaired for \$11 million in 2014 (Scott, 2014; Table 1).

\section{Illinois}

No reports of recent sinkhole damages were found for Illinois. Most sinkholes in Illinois are in rural areas in the southern part of the state.

\section{Kentucky}

Kentucky is one of the few states that have attempted to keep a sinkhole collapse database and to quantify the cost of sinkhole collapses. Cover-collapse sinkholes in Kentucky cause about $\$ 20$ million in damage per year

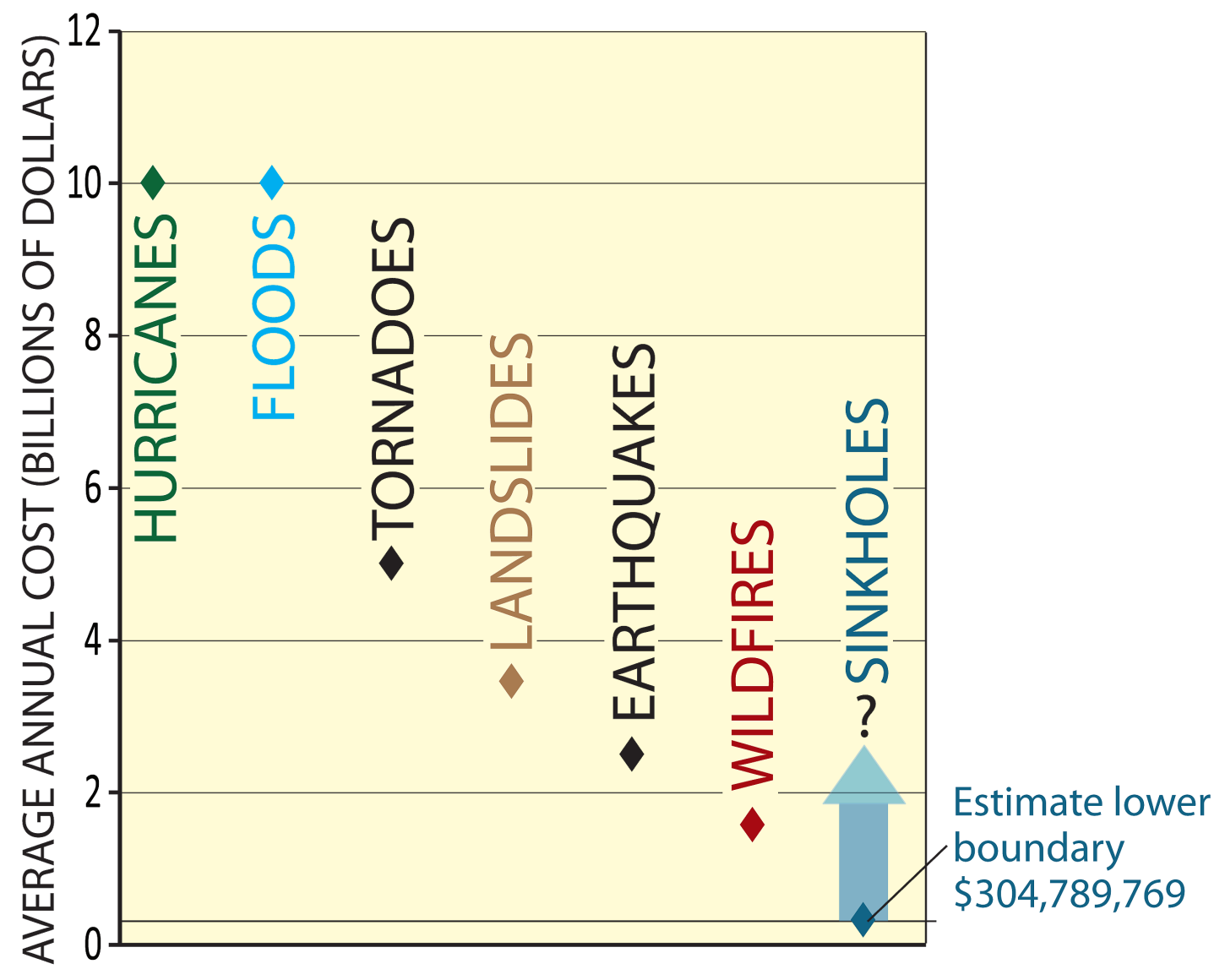

Figure 3. Estimated average annual cost of various natural disasters in the United States, Amounts are unadjusted for inflation. See text for references. 
(Currens, 2012). This figure includes Kentucky Department of Transportation highway repairs of sinkhole damage.

\section{Maryland}

Frederick County has been a hotspot for sinkhole collapse incidents in Maryland in recent years, as there is a combination of geology conducive to sinkhole formation and urban development of the greater City of Frederick area (Brezinski, 2007). The Frederick County hazard mitigation plan (2010) lists several examples, but only one entry includes a dollar amount: $\$ 2,000,000$. A sinkhole collapse of a road in Washington County in 2007 cost $\$ 217,141$ to repair (Table 1).

\section{Minnesota}

No cost amounts for specific incidents were found, although the Minnesota state hazard mitigation plan (2014) lists several incidents of sewage lagoon collapses into sinkholes.

\section{Missouri}

Missouri is extensively underlain by Paleozoic carbonate rocks in the Ozark Plateau region. Because of extensive areas of thick soil or residuum over soluble rocks, some parts of Missouri are particularly vulnerable to covercollapse sinkholes. The Missouri State Hazard Mitigation Plan (2013) designates counties with the most topographic sinkholes, but does not list specific collapse or subsidence incidents. Those counties are: Cape Gerardo, Christian, Dent, Greene, Howell, Oregon, Perry, Shannon, St. Genevieve, St. Louis, and Texas. A USGS Factsheet on sinkholes in Missouri (Kaufman, 2007) listed a few notable collapses but does not include any cost statistics. An examination of the Missouri Department of Insurance website did not reveal any sinkhole-related statistics.

Easily identifiable incidents with costs for the period 2000-2014 added up to only $\$ 1,930,000$ or an annual average of $\$ 128,666$ (Table 1). Based on an extensive bedrock geology that is prone to karst sinkhole development, this amount surely underestimates the actual cost of sinkhole damages in Missouri.

\section{New Jersey}

The 2014 State Hazard Mitigation Plan lists several sinkhole collapse incidents since 2000 but no cost data are available. Most natural sinkholes occur in the northwestern part of the state, particularly in Warren County (New Jersey, 2014).

\section{North Carolina}

The 2013 North Carolina State hazard mitigation plan discusses the geology of natural sinkholes which are concentrated in the southeastern coastal plain part of the state. No sinkhole damage costs were listed (North Carolina, 2013).

\section{Pennsylvania}

Abundant sinkhole locations in Pennsylvania include the Saucon Valley of Lehigh County, the greater Harrisburg metropolitan area in Dauphin and Cumberland Counties, and the Nittany Valley in Blair, Centre, and Clinton Counties (Pennsylvania Emergency Management Agency, 2013).

Easily identifiable incidents with costs for the period 2000-2014 totaled \$28,404,422 and averaged $\$ 1,893,628$ per year (Appendix I).

\section{South Carolina}

The South Carolina state hazard mitigation plan (2013) discusses sinkholes, natural and man-made, but contains no loss data. Sinkholes that damaged municipal buildings and private property in the city of Georgetown in 2011 caused at least $\$ 4,167,280$ in damages (Table 1).

\section{Tennessee}

Tennessee has numerous sinkhole incidents and, in addition to Florida, is the only state to require all insurance providers to offer sinkhole insurance. The 2013 Tennessee State Hazard Mitigation Plan lists only one historical sinkhole incident and identifies broad areas of the state, based on the mapping by Weary, (2008) as having potential for subsidence or sinkholes (Tennessee, 2013). There is also a map of land subsidence hazard relative risk index by county that was generated in a GIS. The index ranges from 1 to 6 , with 6 being the highest. The index was apparently based on area of each county underlain by potentially karstic rocks.

Easily identifiable incidents with costs for the period 2000-2014 totaled only $\$ 696,450$ or an average of $\$ 46,430$ per year (Table 1). Very few incident reports were available in this karst-rich state, so the amounts obviously underrepresent the actual costs.

\section{Texas}

Karst terrain in Texas straddles the divide between karst in humid climate regimes and karst in arid and semi-arid climate regimes of the United States (Weary and Doctor, 2014). It has extensive areas of karst and numerous natural sinkholes, but apparently has few incidents of cover-collapse failures that damage property. The Texas state hazard mitigation plan (2013) includes sinkholes as a subcategory of land subsidence. It lists only 2 specific sinkhole incidents: one in Wink (the Wink Sinks), Winkler County in 1980, and the other at Daisetta, Liberty 
County in 2008. Both of these incidents are associated with dissolution of evaporite rocks at depth and were probably influenced by drilling and fluid injection.

\section{Virginia}

The Virginia hazard mitigation plan lists several historical sinkhole collapse incidents but provides little cost information (Virginia, 2013). The Virginia Department of Transportation (VDOT) has some record of cost data associated with sinkhole repairs to highways and roads and it has been roughly estimated that about $\$ 8$ million dollars were spent on sinkhole repairs over the years 2000-2014 (B. Bruckno, VDOT, 2015, personal communication).

\section{West Virginia}

The West Virginia statewide standard hazard mitigation plan categorizes karst hazard as a type of land subsidence, but lists no specific incidents or costs (West Virginia, 2013). It does suggest that the West Virginia Department of Transportation collect data for future reports on highway damage costs. Sinkhole hazard in West Virginia occurs mostly in the eastern parts of the state, particularly in the Greenbrier Valley and in the Eastern Panhandle.

\section{Results}

Over the last 15 years (2000-2014) sinkhole collapse and karst subsidence has cost on average, at least $\$ 304,316,761$ per year, based on the sum of costs listed in Table 1, as well as the costs reported for Florida, Kentucky, and Virginia.

\section{Comparison of karst subsidence costs with other natural hazards/disasters}

Natural hazards are natural processes which cause loss of life, injury, or health impacts to people; property damage; social or economic disruption; or environmental damage. A natural disaster is a disruption of the functioning of a community or a society involving widespread human, material, economic, or environmental losses and impacts that exceed the recovery ability of the affected community or society (Holmes and others, 2012). A disaster usually occurs as a single event or series of events.

Since data are quite sparse, comparing the annual costs of karst subsidence damage to the better-known natural hazards is difficult. Most of the direct cost of a subsidence event may be the repair or replacement of damaged structures, repairs to infrastructure, particularly roads and bridges, and loss of real estate values.
Natural hazards and disasters in the United States result in direct costs averaging many billions of dollars annually. These include: floods (about $\$ 10$ billion per year) (The Association of State Floodplain Managers, 2013), hurricanes and cyclonic storms (about $\$ 10$ billion per year; Pielke and others, 2008), tornadoes (about $\$ 5$ billion per year; Simmons and others, 2013), landslides (\$3.5 billion per year; Kjekstad and Highland, 2008; Shuster and Highland, 2001), earthquakes (about \$2.5 billion per year; Vranes and Pielke, 2009), wildfires (about $\$ 1.5$ billion per year in federal suppression costs alone; National Interagency Fire Center, 2014), volcanic eruptions (rare but costly), and tsunamis (rare, but potentially very costly). Based on the information collected in this report, sinkhole damages in the United States average at least $\$ 300$ million per year. Figure 3 illustrates the relative annual cost of natural hazards and disasters, including sinkholes, in the United States.

\section{Discussion}

The estimated annual cost of sinkhole damage, \$304 million per year, is a very conservative minimum figure that is based on the relatively few incidents that are documented in this report. Complete information about the cost of damage by karst subsidence incidences is not available. These include: unreported property damage to private, commercial, and government buildings; and most of the cost of highway repairs (except for the losses reported in Kentucky and a few other incidents in other States).

If a full accounting were possible for the total actual costs of sinkhole damage, it is likely that annual damages would be significantly higher than the amount reported here.

In compiling information for this report, no karst cost information was found from several states that have karst and therefore must have at least some occurrence of sinkhole damage. Addition of these losses will increase the national cost estimate.

State geological surveys generally are good possible sources for obtaining karst subsidence and sinkhole collapse cost information aware of the extent of karst lands and the potential of karst hazard within their respective states. Some of these surveys keep records of sinkhole incidents, but most do not have the funding or political mandate to obtain and keep records programmatically. Perhaps a survey initiated by an organization such as the American Association of State Geologists (AASG) could poll the state geological surveys for known incidents and cost estimates. 
As mentioned earlier in this report, each state has a hazard mitigation plan, which includes a format for karst, sinkhole, or ground collapse hazard description and historical incidence. These descriptions are usually generalized and detailed data are generally not easily available. Many of the states rely on their geological surveys to complete this portion of their mitigation plan and so these surveys it may be better primary sources. At the federal level perhaps FEMA could encourage greater reporting detail in those state plans.

In some states insurance organizations and regulators collect karst subsidence and sinkhole collapse damage information such as Florida did in a data call to their property insurers (Florida Office of Insurance Regulation, 2010). This data call represented an investment in time and money and was driven by the mounting losses to sinkhole insurance claims in Florida, a situation that has not occurred in other states. Without such a driver, it is difficult to mandate similar calls elsewhere, but voluntary surveys may be a possibility.

There is some information available through State Departments of Transportation, generally from archived news releases and public contract awards. An organization such as the American Association of State Highway and Transportation Officials (AASHTO) could sponsor a specific survey of State highway maintenance engineers. Once again, there is the problem of highway department's generally not recording sinkholes as a unique type of damage repair and because of the need for a geologist or engineer to separate karst incidents from other types of collapse.

Of course there is also potential karst information and informational contacts available through the many karst scientists in in the United States. The Geological Society of America (GSA) recently added a Karst Division (2014) which could access a large contact list for information and suggestions on defining the karst hazard. Likewise, the National Cave and Karst Institute (NCK$\mathrm{RI})$ could also reach out to its contacts and friends for information.

\section{References}

Alabama Emergency Management Agency. 2013. State hazard mitigation plan update. Alabama Emergency Management Agency. Clanton (AL). Available from: http://ema.alabama.gov/filelibrary/AL $\% 20$ Standard\%20State\%20Mitigation\%20Plan.pdf

Association of State Floodplain Managers. 2013. Flood Mapping for the Nation. Report 3/1/2013. p. 15

Brezinski DK. 2007. Geologic and anthropogenic factors influencing karst development in the Frederick region of Maryland: Environmental Geosciences 14 (1): 31-48.

Carey DI, Hounshell TD, Kiefer JD. 2008. Geologic hazards in Kentucky: Kentucky Geological Survey, Map and Chart 185, Series XII. Available from: http://kgs.uky.edu/KGSWEB/OLOPS/PUB/KGS/ MC185_12.PDF

Currens JC. 2012. Cover-collapse sinkholes in Kentucky, USA: geographic and temporal distribution. Carbonates and Evaporites 27: 137142. Available from: http://link.springer.com/ article/10.1007\%2Fs13146-012-0097-2\#page-1

Florida Office of Insurance Regulation (OIR). 2010. Report on Review of the 2010 Sinkhole Data Call (OIR Report). 33 p. Available from: http://www. floir.com/pdf/2010_Sinkhole_Data_Call_Report. pdf

Frederick County, Maryland. 2010. Frederick County hazard mitigation plan. Frederick County Department of Emergency Preparedness, Frederick (MD). 140 p. Available from: http://www. brunswickmd.gov/wp-content/uploads/2012/01/ Frederick-County-Hazard-Mitigation-Plan-Finall. pdf

Federal Emergency Management Agency (FEMA). 1997. Multihazard identification and risk assessment, a cornerstone of the national mitigation strategy. Federal Emergency Management Agency. Washington, D.C. 365 p. Available from: https://www.fema.gov/media-library/assets/ documents/7251

Ford DC, Williams P. 2007. Karst hydrogeology and geomorphology: Chichester, England: John Wiley $\&$ Sons Ltd.

Galloway D, Jones DR, Ingebritsen SE. 1999. Land subsidence in the United States. U.S. Geological Survey Circular 1182.

Georgia Emergency Management Agency. 2014. State of Georgia hazard mitigation strategy. Georgia Emergency Management Agency. Atlanta (GA). Available from: http://www.gema. ga.gov/Mitigation/Resource $\% 20$ Document $\% 20$ Library/2014\%20GHMS.pdf

Holmes RR Jr, Jones LM, Eidenshink, JC, Godt JW, Kirby SH, Love JJ, Neal CA, Plant NG, Plunkett ML, Weaver CS, Wein A, Perry SC. 2013. U.S. Geological Survey natural hazards science strategy-promoting the safety, security, and economic well-being of the Nation. U.S. Geological Survey Circular 1383-F.

Kaufmann JE. 2007. Sinkholes. U.S. Geological Survey Fact-Sheet 2007-3060. Available from: http://pubs. usgs.gov/fs/2007/3060/pdf/FS2007-3060.pdf 
Kjekstad O, Highland L. 2008. Economic and social impacts of landslides. In: Sassa K, Canuti P, editor. Landslides - Disaster Risk Reduction. Springer Science \& Business Media. p. 573-587.

Minnesota. 2014. Minnesota State hazard mitigation plan. Department of Public Safety, Division of Homeland Security and Emergency Management, Saint Paul (MN). Available from: https://dps. mn.gov/divisions/hsem/hazard-mitigation/ Documents/State\%20Plan\%20Final\%202014.pdf

Missouri. 2013. Missouri State hazard mitigation plan. State of Missouri Emergency Management Agency, Department of Public Safety, Jefferson City (MO). Available from: http://sema.dps.mo.gov/ docs/programs/Logistics, \%20Resources, \%20 Mitigation\%20\&\%20Floodplain/mitigation/MO_ Hazard_Mitigation_Plan_2013.pdf

National Interagency Fire Center. 2014. Federal firefighting costs (suppression only). National Interagency Fire Center, Boise (ID). Fact Sheet. Available from: https:/www.nifc.gov/fireInfo/ fireInfo_documents/SuppCosts.pdf

New Jersey. 2014. State of New Jersey 2014 hazard mitigation plan, Section 5.7 Geological hazards. New Jersey Office of Emergency Management, West Trenton (NJ). Available from: http://www. ready.nj.gov/programs/pdf/mitigation 2014b/ mit2014_section5-7.pdf

North Carolina. 2013. North Carolina hazard mitigation plan, appendix A-3. North Carolina Department of Public Safety, Raleigh (NC). Available from: https://www.nccrimecontrol.org/div/EM/ HazardMitigation/StateHMPlan/2013updatedAp pendixA3LesserHazardsRiskAssessmentFINAL. doc

Pennsylvania. 2013. Pennsylvania 2013 standard state all-hazard mitigation plan. Pennsylvania Emergency Management Agency, Harrisburg (PA). Available from: http://www.portal.state.pa.us/ portal/server.pt/document/1378383/pennsylvania state_hazard_mitigation_plan_-_oct_31_2013_pdf

Pielke RA, Gratz J, Landsea CW, Collins D, Saunders MA, Musulin R. 2008. Normalized hurricane damage in the United States: 1900-2005: Natural Hazards Review 9 (1): 29-42.

Scott K. 2014. Monroe County Airport repairs airport sinkholes.Airport Improvement 13:62-65.Available from: http://digital.airportimprovement.com/ Vizion5/viewer.aspx?issueID $=13 \&$ page ID $=63$

Shuster RL, Highland LM. 2001. Socioeconomic and environmental impacts of landslides in the western hemisphere. U.S. Geological Survey Open-File Report 01-0276. Available from: http://pubs.usgs. gov/of/2001/ofr-01-0276/
Simmons KM, Sutter D, Pielke RA. 2013. Normalized tornado damage in the United States: 1950-2011: Environmental Hazards 12 (2): 132-147. Available from: http://dx.doi.org/10.1080/17477891.2012.7 38642

South Carolina. 2013. South Carolina hazard mitigation plan. South Carolina Emergency Management Division, West Columbia (SC). Available from: http://www.scemd.org/files/Mitigation/State Hazard_Mitigation_Plan/1_SHMP_FINAL_2013. pdf

Tennessee. 2013. State of Tennessee Hazard Mitigation Plan. Tennessee Emergency Management Agency, Nashville (TN). 621 p. [File available on request at: http://www.tnema.org/ema/response/plans.html]

Texas. 2013. State of Texas hazard mitigation plan. Texas Department of Public Safety, Austin (TX). Available from: http://www.txdps.state.tx.us/dem/ documents/txhazmitplan.pdf

U.S. Army Corps of Engineers. 2012. Clearwater Dam major rehabilitation, MO. U.S. Army Corps of Engineers, Little Rock District, Fact Sheet. Available from: http://www.swd.usace. army.mil/Portals/42/docs/civilworks/Fact $\% 20$ Sheets/Little\%20Rock/FY13\%20Clearwater\%20 Major\%20Rehabilitation,\%20MO.pdf

U.S. Army Corps of Engineers. 2014. Rough River, Kentucky Dam Safety. U.S. Army Corps of Engineers, Louisville District, Fact Sheet. Available from: http://www.lrl.usace.army.mil/Portals/64/ docs/Congress/201409/Kentucky/KY.pdf

U.S. Army Corps of Engineers. 2015. Center Hill Dam safety rehabilitation project: U.S. Army Corps of Engineers, Nashville District, Fact Sheet. Available from: http://www.lrn.usace.army. mil/Media/FactSheets/FactSheetArticleView/ tabid/6992/Article/493792/center-hill-dam-safetyrehabilitation.aspx

Virginia. 2013. Commonwealth of Virginia hazard mitigation plan. Virginia Department of Emergency Management and the Virginia Tech Center for Geospatial Information Technology. Section 3.14. Available from: http:/www.vaemergency.gov/ webfm_send/853/Section3-14-KarstTopography. pdf

Vranes K, Pielke R Jr. 2009. Normalized earthquake damage and fatalities in the United States: 19002005. ASCE, Natural Hazards Review, August 2009, p. 84-101.

Weary DJ. 2008. Preliminary map of potentially karstic carbonate rocks in the central and southern Appalachian states. U.S. Geological Survey Open-File Report 2008-1154, scale 1:2,000,000. Available from http://pubs.usgs.gov/of/2008/1154/ 
Weary DJ, Doctor DH. 2014. Karst in the United States: a digital map compilation and database. U.S. Geological Survey Open-File Report 20141156. Available from: http://dx.doi.org/10.3133/ ofr20141156.

West Virginia. 2013. West Virginia standard hazard mitigation plan update. West Virginia Division of Homeland Security and Emergency Management. Supported by Dewberry, Fairfax (VA). Available from: http://www.dhsem.wv.gov/ MitigationRecovery/Documents/2013\%20 WV\%20Statewide\%20Hazard\%20Mitigation\%20 Plan\%20Update.pdf 
446 NCKRI SYMPOSIUM 5 14TH SINKHOLE CONFERENCE 